\title{
Historic Places and Buildings in Yoruba land
}

\author{
Titilayo Anifowose and John Olatubosun
}

\author{
Department of architecture \\ University of Lagos Akoka
}

Nigeria

\begin{abstract}
This paper is a synopsis of historic places and building in Yoruba southwest of Nigeria, the communication of historic places and traditional Yoruba architectural character in selected buildings within the Yoruba environment. With view to encourage and promote the indigenous identity/image through architectural character and features in the historic places. Information was assembled through literature, field observations from case studies of traditional Yoruba buildings, (through random selection) from major Yoruba towns, in Nigeria. The historic places and buildings were reviewed and descriptively obtained. Findings among others revealed that historic places and buildings speak volume about the traditional custom of the people and that the traditional Yoruba Architectural character is been derelict because of the influence of foreign character through materials" choice and technology, and has become a threat to the conservation of cultural identity/beliefs and custom. This paper therefore identifies the historic places characters and traditional Yoruba architecture and recommends how to celebrate the imperative legacy in Yoruba and develop strategies for branding Cultural/National identity.
\end{abstract} 1

Keywords: Historic Places, Traditional Yoruba Architecture, Cultural identity, Custom, Historical Monuments, Heritage.

\section{INTRODUCTION}

Nigeria has rich cultural heritages infiltrated in her language, songs, traditional religious practices, folktales, lore, chants, history, literature and general worldview. Her diversity, borne out of her diverse components and numerous ethnic group, add to the understanding of her cultural heritages. Nigeria is a country made of people with diverse cultural backgrounds and this is exhibited in the buildings and monuments that they have erected to denote their beliefs and history [1-2]. The physical appearance of a city is a direct image of its people, culture, and history. The historic environment is the cultural landscape of our community. It represents the antique records of the incremental advancement of our society and localities. The role of historical places and building in Yoruba land cannot be over stressed. It is an unpretentious medium that Yoruba's make their cultural heritage known from one generation to the other [3] Due to the rigidity of the medium of exchange of cultural heritage, it stands the risk of being lost or forgotten. In Nigeria the preservation of listed buildings and structures is vested in the National Commission for Museum and Monuments. It is dejected to note that there is considerable dearth in terms of literature regarding historic places and building in Nigeria when related with other countries. The benefit of preserving these historic places and buildings are quite great and a lot needs to be done in this area this is evident by the number of historic places and buildings available in the database of National Commission of Museum and Monument [4]

\section{METHODOLOGY}

Qualitative research method was used during the course of this research; here by drawing facts from academic scholarly researches and exploratory study. Having selected southwestern part of Nigeria as the central case study, this is aimed at understanding the features in some historic places and building in Yoruba the southwestern part of Nigeria. The components of this research will be grouped in stages ranging from the collection of fact about the two historic places and two building from two significant buildings in two Yoruba palaces in southwestern Nigeria.

\section{SUMMARY OF FINDINGS AND DISCUSSION}

Yoruba historic places symbolize her unique epitome, peculiar and identity. Representing important historical styles and occasions, replicating the lives of important personnel, enlightening unique architectural, engineering, and artistic design 


\section{International Journal of Advances in Scientific Research and Engineering (ijasre), Vol 5 (6), June-2019}

achievement, and imparting information about Yoruba's past, historic places tell fascinating stories of the states, and of the communities in the south west geopolitical zone of Nigeria. The World Bank (2006) also recognizes that physical cultural resources are important as sources of treasured scientific and historical information, as resources for economic and social advance, and as integral parts of a people's cultural identity and practices. Historic places are cultural heritage that is value by the people to an objects and places through their association with those objects and places. These values include those significance to indigenous people, places of social value to the community, and places of historic, architectural or scientific significance, and therefore encompass both indigenous and historic heritage. Two major historic places are discussed below;

\subsection{Olumo Rock}

Olumo rock is an historical monument, functioned as a shelter and fortress to the Egba people during the Yoruba wars. By 1930, the bulk of the Egba"s had already settled at the site of Olumo Rock and the refuge provided by the rock marked the end of their wanderings and fights for existence. Since then, they regard the Olumo rock as their protective shrine and they make annual ransoms to its deity. Olumo Rock is located in the traditional core of Abeokuta Town in Ogun State, Nigeria. The rock is the most important tourist attraction in the state. The Olumo rock is a massive outcrop of granite rock, pre-cambrian geological formation. It is located between Ikija and Ikereku neighborhoods and visible from all parts of the city. Abeokuta, the capital of Ogun state derives its name from this rock. Abeokuta lies southwest of the Republic of Nigeria, and is 100 kilometers from Lagos, the commercial nerve of Lagos, to the north, and to the south some 70 kilometers away from the city of Ibadan.

The highest point on the Olumo rock is about 137 meters above sea level. The Ogun River which gives the name of the state flows west of the Olumo rock. The name „Olumo" means "God built it.” It is surrounded by a lot of caves within which the Egbas took refuge in the time of Yoruba inter-cities war. One of such caves, which are about $6 \mathrm{~m}$ by $7 \mathrm{~m}$ wide, has slab-like stones that must have served as seats for ancient occupiers around the cave. Olumo rock is a traditional monument, assisted as a housing and fortress to the Egba people during the Yoruba wars. People from all walks of life still come here for divine consultation.
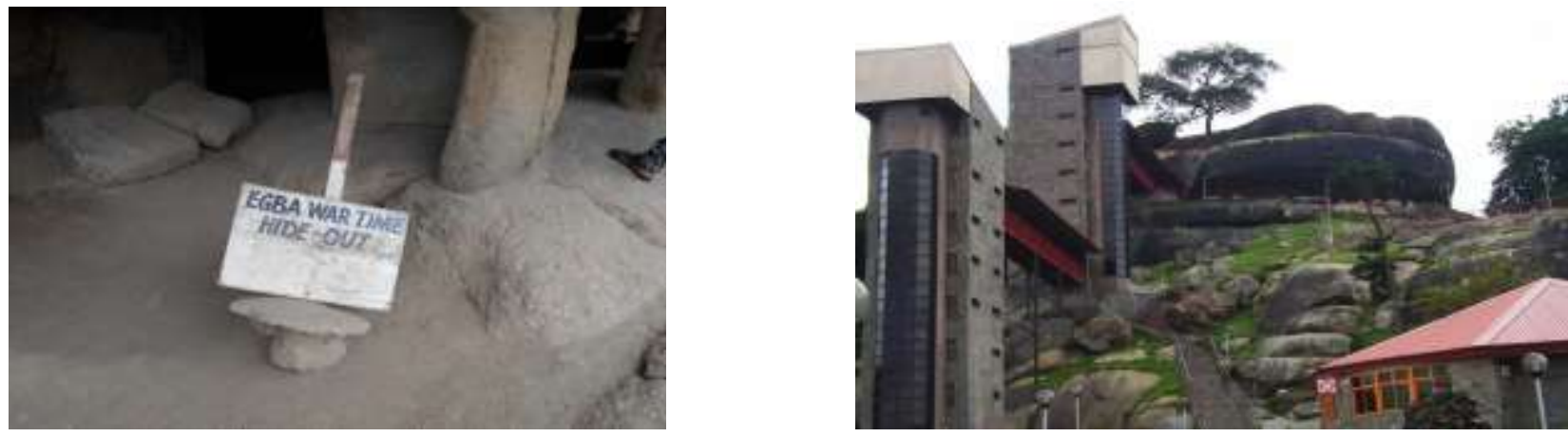

Figure 1. Picture showing olumo rock as a fortress and tradition monument of Egba people

A 200 years old tree still grows at the apex of the Olumo Rocks thereby standing out as an active tourist destination of great choice. To the Egbas, Olumo Rock opinions not only as a monument of faith and unity but also a source of strength and unfailing protection and sustenance from the Supreme Being who led their ancestors through the perplexes of life carefully to their land of sojourn, Abeokuta. Olumo rock is a world class tourist destination that stands, as the only one of its kind in Africa and presumably the world. The center consists of a hotel, games hall with facilities for indoor sports games, fast food, and culture gallery, a giant telescope to view Abeokuta, a fountain of atonement, a health pond, a recreational park, an amphitheater among others. The center also has a heavy duty escalator and a class elevator running the different levels of the rock alongside with the old stair way for visitors who loves uphill. 


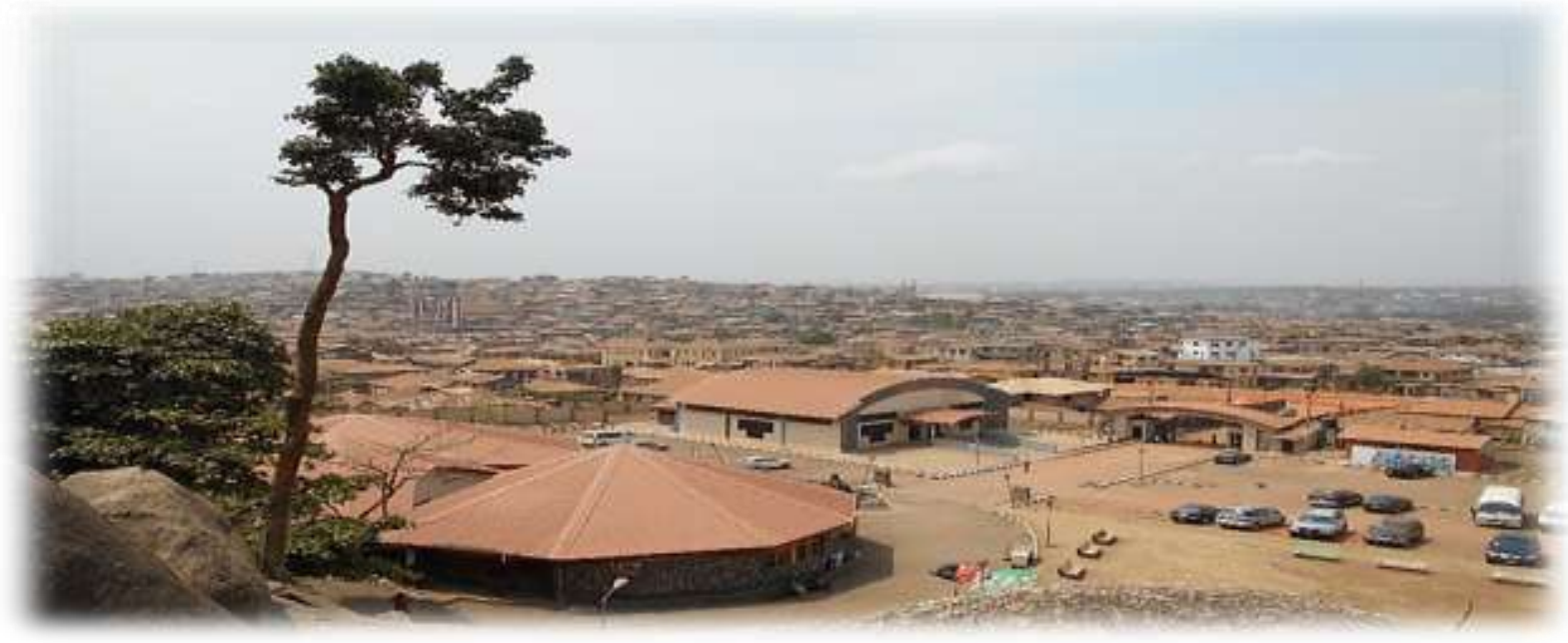

Figure 2. Picture showing some features in olumo rock

\subsection{Idanre hill}

Idanre hills is recognized to be among the greatest cultural heritage of Yoruba and Nigeria as a whole. This natural legacy has brought the whole Idanre community into publicity and fame. "The ancient Idanre hills are spectacular tourist attractions. Idanre town where these hills are located is about $15 \mathrm{~km}$ southwest of Akure, the Ondo state capital. There is ancient town, which is at the hill top and the new settlement at the foot of the hills. The Idanre hills, which are steep-sided, smooth and dome-shaped in nature, present an irresistible sight. The different hills were named after some historic facts in the sociocultural evolution of Idanre land. Some of these are the Olofin and Orosun Hills named after Olofin, the pioneer Oba of Oke- Idanre and his queen in that order. The Agbogun footprint presents an attractive specter of a mythical shoeprint which could fit into the size of anyone who put their foot into it, regardless of the size of their foot. It was revealed that Agbogun served as a traditional probing device for discovering people with witchcraft or other familiar spirits in the olden days. The ancient traditional palace, which is a reflection of the ingenious African architecture, is also interesting to behold.
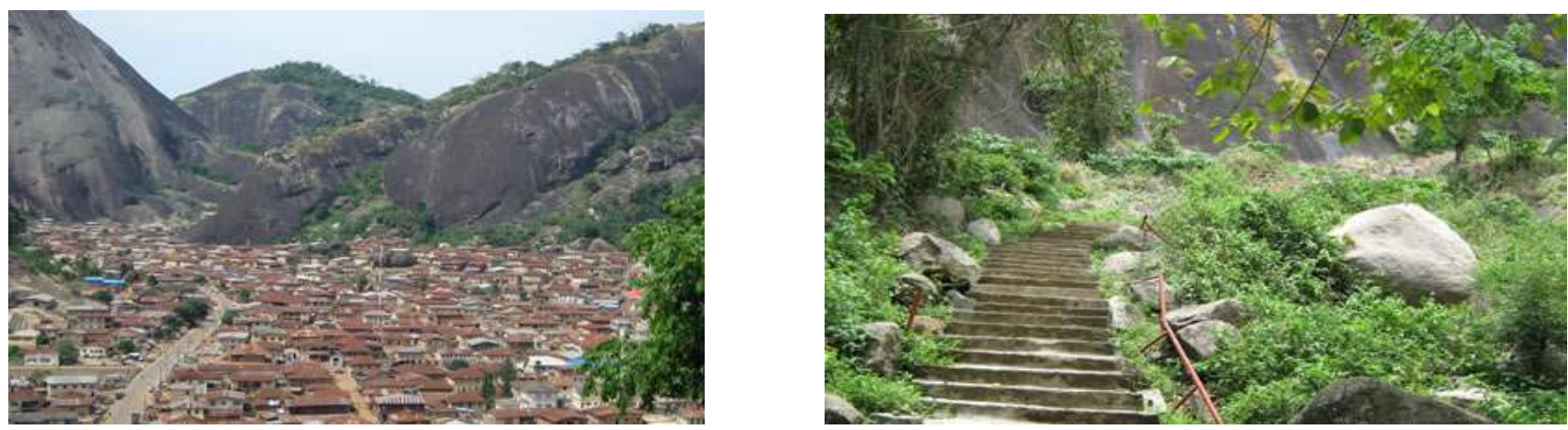

Figure 3. Pictures showing Idanre hill

There is also Carter Hills named after a former Colonial Governor who signed a peace treaty with the Oba of Idanre in 1891. The Ajimoba Hill was named after a gateman, while the Ilesun Hill was named after an ill-fated daughter of a great warrior who killed his daughter in fulfillment of his promise to sacrifice the first living thing that comes his way if he should be victorious in his war exploit. The girl was buried near the Ilesun Hill and every year, there is a commemoration ceremony on the hill by children of her age. Idanre Hills in the past offered protection against invaders and are worshipped annually. The cultural remnants in terms of god, goddesses and traditional arts and crafts can still be seen in addition to the old palace built around the 17 th century. To get to the top of the hill, tourists will have to climb 640 steps with five resting posts along the steps where tourists can take a rest.

The architecture of the ancient Yoruba of Southwest Nigeria was a joint attempt and that building was a statement of ideological, economic and social position in the larger urban context. Generally, architecture is dependent on culture, which, in simple terms, represents the way of life of people. The structure of the Yoruba building is designed and built based upon a person's social background, part from the living quarters within a compound, other forms of architecture like the palace and shrines are designed and built as the society's social mandate. The palace in particular is built in such a way as to house the entire community. It is an emblem of their wealth, riches, beliefs, and a cultural property. The Yoruba are recognized for their wooden sculptures which are mainly used as door panels, veranda posts, pillars, and stools in their buildings. They also carve thousands of symbolic sculptures 
which are either used for religious or functional drives. Aside from their art in wood, they are excellent workers of metal, casters of Brass and Bronze, calabash carvings, bead works, and traditional wall ornamentation. All these numerous artistic events are executed either along with, or in support of Yoruba indigenous architecture, which is relatively eternal in structure

\subsection{History of Egba Ake in Abeokuta}

Early history of the Egbas revealed, Sodeke paraded the main body of the Egba survivors of the Yoruba civil wars out of Ona River in Ibadan to the strong fall of the rock by 1830. Immediately after settling down in Abeokuta, Sodeke re-organized the social structure of the Egba Nation in such a way that the political system of local administration otherwise referred to as traditional authority was introduced in order to check the lawlessness, overriding excesses and atrocities often committed by the then powerful Warlords and chiefs of the period. This system later grew out of the public meetings that Sodeke, in his position, as the Balogun of Egbas always convened, the first at Sodeke square at Iporo and later at Ake square. Although, this system of governance was initially considered crude it respected the liberty of individuals. From 1830-1845, Sodeke held the leadership position creditably as Balogun of the Egba until he died in January 1845.

After his death, Abeokuta had no leader for some years. The government of the town was left in the hands of those powerful war chiefs like Somoye, Apati, Akodu, Sokenu. In 1846 when Revd. Henry Townsend visited Abeokuta for the second time, he observed that the Egbas who had practiced monarchical governance in their pre- war years had no king and he advised them to have one. This was the moment the Egba people realized the fact that they were not as united as they were when Sodeke was alive. The thought of having an Oba (king) then came to focus. The lot fell on Okekenu, the Sagbua of Ake who was the head of Egba Ogboni. Okekenu was selected on the $8^{\text {th }}$ may, 1854 as Alake elect. After his selection, Okekenu saw the pressing need for the Egba Chiefs from all sections of Abeokuta to have common venue for holding their regular seventeen days (Itadogun) meetings where the chiefs would be privileged to meet and exchange ideas on how to foster good administration. This was what brought about the initiation of the first palace building in Egba Ake's palace.

\subsection{The First Egba Ake Palace Building}

Ake's palace is the executive organ of the Egba Ake town, which is the center of development around which Egba Ake evolved. The palace comprised the ancient museum and religious centers within which the city function and developed. Ake's palace is the seat of the paramount ruler of Egbaland. The first Ake Palace building was structured in letter ' $L$ ' shape and completed in 1854 in preparation for Okekenu ist installation on $8^{\text {th }}$ August 1854 as the first Alake of Abeokuta. It was decorated with different shapes of carved woods depicting art and culture of the city, thus pointing to the professional trade of Okekenu as an industrial wood carver. The Palace building consisted of five rooms leading to a large open space provided in front of the rooms with a large veranda supported by twelve heavily molded poles serving as columns (owon). The veranda served as a venue where the Alake used to engage the Ogboni and war chiefs in private discussion. It was also used by the Alake in listening to various complaints from the community who sought for redress. This venue was and still referred to as "Idiere" or "Dipomu" at the Alake Palace.

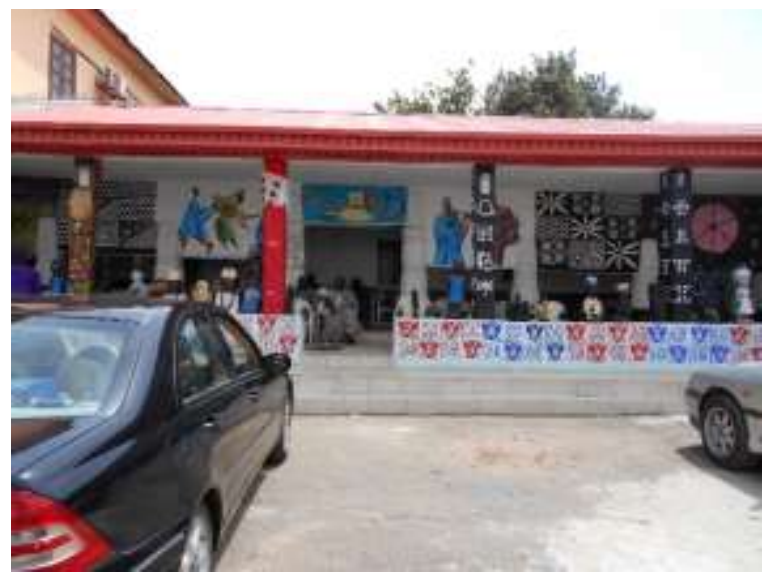

Figure 3.a Idiere (Dipomu). Ake palace

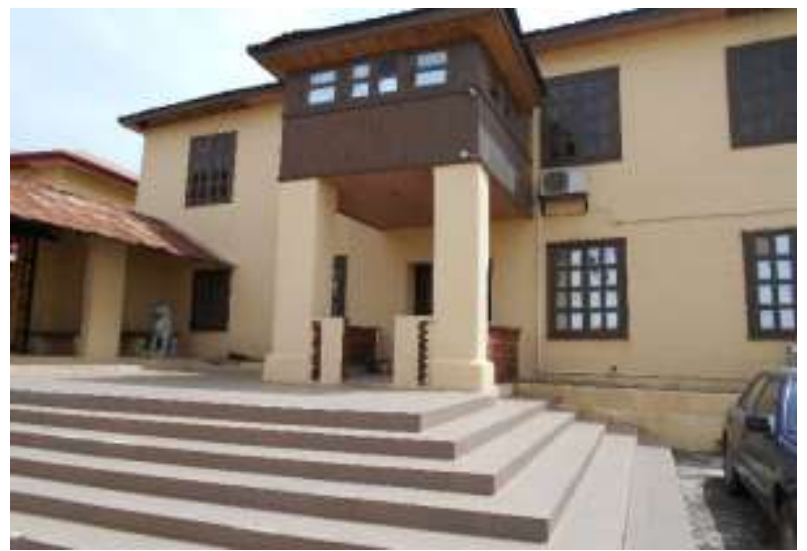

Figure 3,b The first Ake palace building

\subsection{History of Akure}

Akure Kingdom is a traditional state with headquarters in Akure, Ondo State, Nigeria. It is the heir to an ancient Yoruba city state of the same name. The ruler bears the title "Deji of Akure". Verbal tradition states that Akure was founded by a prince named Omoremi, son of Ekun and grandson of Oduduwa Omoluabi, the royal antecedent of the Yoruba tribe. The Prince left Ile-Ife, his grandfather's kingdom, in search of a place to settle after passing a strict test administered by Oduduwa himself. This test wherein he was kept in isolation for about nine (9) days is still annually commemorated in Akure today by the reigning king of the town 
during a ceremony known as 'Oba wo ilesunta'. At the point where the prince and his revelry arrived at the exact location of the modern city, the string holding the heavy royal beads on his neck is said to have shattered, thus causing the people to exclaim "Àkún rę" (or The beads have snapped), this later becoming the name of the settlement they established on the site.

Over time, the phrase was whittled down through its constant use to become Akure.

Omoremi is said to have startled with his entourage while on his way from Ile Ife. He arrived in Akure and was proclaimed the Person who hunted and arrived with royalty, i.e., Asodeboyede. The palace that was built to house him still stands and dates to $1150 \mathrm{AD}$.

Originally, the kings of Akure that were born of him were referred to as Ajapada. The title Deji of Akure started with Oba Arakale, whose father took the daughter of Oba Atakumosa, the Owa of Ijeshaland as one of his wives while the latter was on his way to Benin. By the time Oba Atakumosa was returning to Ilesha from the pilgrimage, his daughter (Owawejokun) had given birth to a son.

While other notables gave the little baby common gifts, Oba Atakumosa was said to have presented his grandson with a small diadem. Owafadeji i.e., Owa gave him a diadem or royal crown became the nickname of the young boy, and by the time he reached his adulthood it had become his de facto name. When Owafa'Deji became Oba, the appellation assumed a ostensible importance and because of his prominence as an Oba, subsequent Obas or kings assumed the title while the advent of the modern era has formally made Deji the official title of the Obas of Akure. However, the original title of Ajapada has remained a significant part of the Deji's ceremonial style till the present day.

Figure 4 shows Uwa Nla (The largest courtyard in Deji's palace

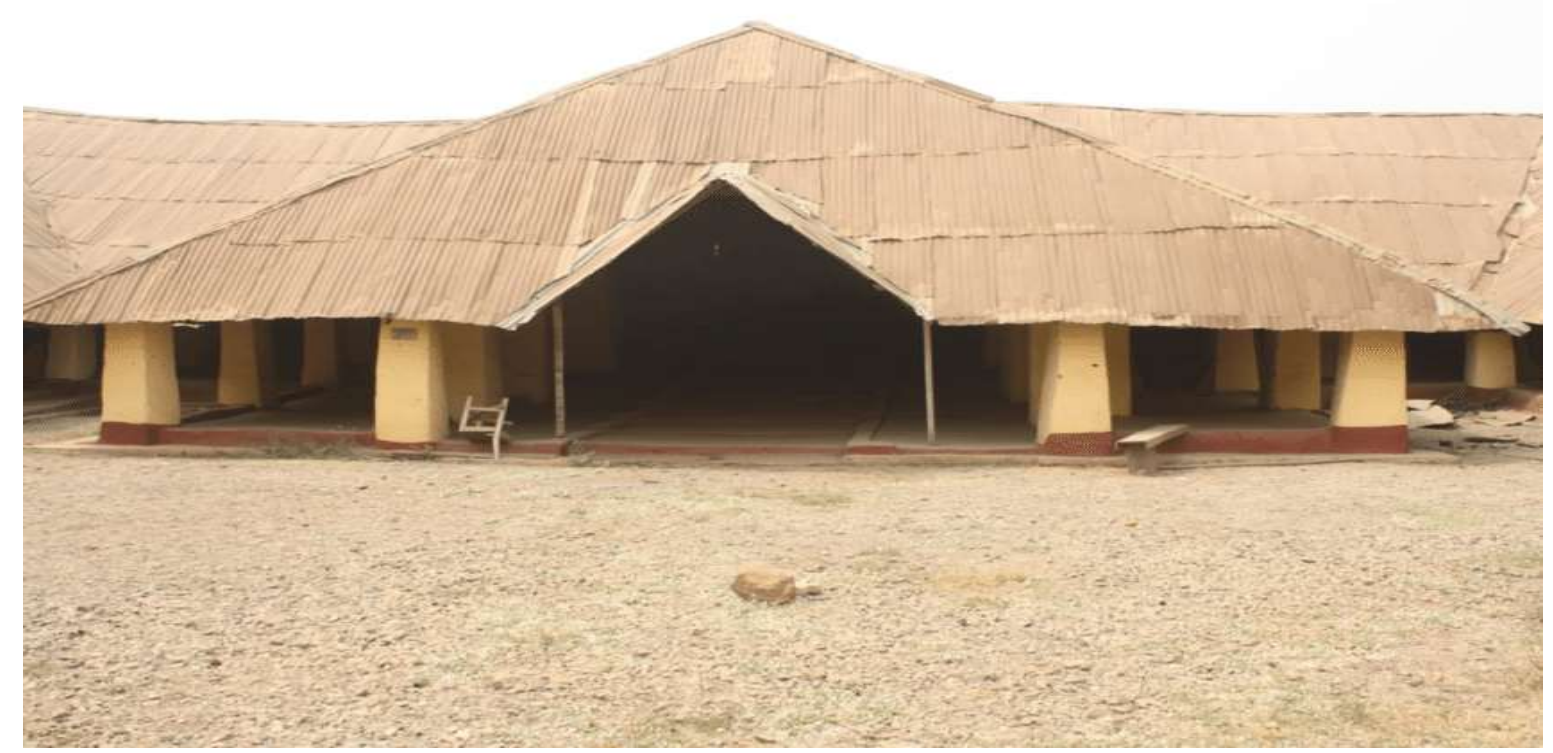

Figure 4. Picture showing the largest courtyard in Deji's Palace Akure

Uwa nla (is the largest courtyard) among the twenty two courtyard in Deji's palace. Deji's palace is sectionalized into three fragment; the lower foyer which lead to the other units of the palace like the twenty two courtyards, the upper foyer that lead to the main palace building and the foyer that lead to the main hall where people meet for different purposes within the palace. Different courtyards are used for different purposes within the palace.

\subsection{Functions of Uwa Nla (largest courtyard)}

This is where people gather together every year to worship different deities within the palace.

It has so many columns that signifies royalty within the palace and also the respect of Akure indigenes to their gods.

It has wide verandah where people sit and communicate during festive period.

The courtyard has seven rooms where different cultural artefacts are kept for posterity sake. This building is one of its kind in Yoruba vernacular building. Although the Oba has relocated to a more modern palace, the old building from 1150 AD is still used for all ceremonies.

\section{CONCLUSION AND RECOMMENDATION}

This study has revealed morphology of some Yoruba historic places and expresses the traditional Yoruba cultural setting, value for safety, religion and culture. Which was put functionally as place of worship, living and socio-interactive spaces within an 


\section{International Journal of Advances in Scientific Research and Engineering (ijasre), Vol 5 (6), June-2019}

enclosure, with the view to creating impressive and aesthetically appealing architectural and symbolic piece(s). It is imperative to preserve cultural heritage and buildings in a manner that both maintain their attractiveness to visitors and the values for which they were preserved. Therefore, a policy should be developed to blend and bring together all cultural heritage in Yoruba land so as to effectively preserve and conserve historic cultural heritage and buildings for posterity. To achieve this, proper funding should be sourced to procure modern equipment to annex all Yoruba cultural heritage and buildings. The resources should also be digitized in order to enhance their visibility. A logical access classification should be evolved with suitable meta-data for digital warehouses and classificatory paradigms for proper information papers and ease of retrieval. Harnessing these resources will not only engender the longevity of the cultural entities and objects, it will also ensure that the historic, physical and archival materials and antiquities preserve the reflections of Nigeria's cultural heritage and identity.

\section{REFERENCES}

1. Oluremi, I. Obateru (2002): The Yoruba city in History 11th century to the present". Penthouse publication, Nigeria.

2. Dmochowski Denyer, S. (1978): "African traditional Architecture: A Historical and Geographical perspectives" Heinemann Nigeria.

3. Ogunba, O. (2002): "The meaning, culture and history of the Yoruba city". The city in Nigeria (eds) Dolapo Amole, Ayo Ajayi and Afolabi Okewole.

4. The National Commission for Museums and Monuments, Lagos.

5. Ajisafe, A. K. (1964). History of Abeokuta. Abeokuta: M.A. Ola, Fola bookshops.

6. Agbo F. (1993) Yoruba Architecture: the years of creativity and the years of decadence. Journal Publication of the department of Fine Art, Obafemi Awolowo University, Ile- Ife. p206.

7. Ashworth G. J. (2003). Conservation as Preservation or as Heritage: Two Paradigms two answers, in Cuthbert A (ed.) Designing Cities: Critical Readings in Urban Design, Oxford: Blackwell Publishing

8. , Z.R. (1990). An introduction to Nigeria traditional architecture. Vols. 1-3,

9. Gardi. (1973). "Indigenious African Architecture". Van Nostrand Reinhold Company.New York. 